\title{
PRAGMATIC MARKERS IN DIALOGICAL DISCOURSE Lidiya Volkova
}

Volkova, L. Pragmatic markers in dialogical discourse // Lege artis. Language yesterday, today, tomorrow. The Journal of University of SS Cyril and Methodius in Trnava. Warsaw: De Gruyter Open, 2017, vol. II(1), June 2017. p. 379-427. DOI: 10.1515/lart-2017-0010

\begin{abstract}
The article presents a study of dialogical discourse operators defined as pragmatic markers. The author introduces a list of special English pragmatic markers - words that are united by the same implicit semantics of contrast. Pragmatic markers of the selected group are used in dialogical discourse as a means of realization of the speaker's communicative intention and serve as illocutionary indicators of indirect speech acts. They are also important components of indirect communicative strategies and tactics.
\end{abstract}

Key words: pragmatic marker, correlation, implicit meaning, illocutionary indicator, pragmatic transposition, indirect speech act, communicative strategy.

\section{Introduction}

Joanna Channell (1994: 1), a researcher and writer on applied linguistics, once wrote: People have different beliefs about language. One of them is that 'good' usage involves (among other things) clarity and precision. Hence, it is believed that vagueness, ambiguity, imprecision, and general woolliness are to be avoided.

However, natural communication proves the contrary. Quite often, for different reasons, we tend not to reveal our real intentions; sometimes what we actually say is not what we mean. There are cases when it is far better to achieve our communicative goals by being not totally explicit. To achieve his communicative intention, the speaker has to choose one of a range of different language and speech means we have at our disposal. Among them, there are discourse markers of a special nature presented in language as function words. In this article, we define them as pragmatic markers because we are going to prove that in dialogical discourse they are able to reveal 
various explicit and implicit pragmatic meanings and accordingly perform numerous pragmatic functions. It should be noted in this respect that meaning is understood in this article as it is defined by Channell - a broad term indicating all the propositions, which a listener can reasonably derive, taking into account contextual and background knowledge (1994: 24).

The aim of this paper is to suggest the mechanism of selecting and investigating the pragmatic potential of a group of small language units serving in speech as pragmatic markers. The material subjected to analysis presents a selection of dialogical fragments taken from novels by contemporary English and American writers. The criterion of the selection was the presence of pragmatic markers under analysis in the dialogical discourse fragments. In the process of the research the following methods were applied: some elements of componential analysis, speech act analysis, and discourse analysis. Componential analysis was used in order to reveal semantic and additional pragmatic components of the pragmatic markers under investigation. The application of speech act analysis made it possible to investigate the illocutionary potential of the pragmatic markers. And finally, discourse analysis allowed us to introduce communicative strategies and tactics where the pragmatic markers in question are used as important components of speech interaction.

Before I go further into my investigation of pragmatic markers, the general notion of discourse markers should be highlighted. Discourse markers are fairly defined in linguistics as "mystery words" (Brinton 2003: 152) or "mystery particles" (Longacre 1976: 468). According to Longacre, mystery particles almost inevitably "have a function, which relates to a unit larger than the sentence, i.e. to the paragraph and the discourse" (1976: 468). Their mysterious nature can be explained by the fact that they lack referential meaning and their scope of action is hard to define, especially for nonnative speakers of English, who learn English as a foreign language, while competent native speakers do not have to seek laboriously for the contextual meaning of a word, phrase or sentence because it is obvious for them (Stubbs 1983:4). 
English discourse markers present quite a numerous group of function words belonging to different grammatical classes. The groundwork for studying discourse markers was laid by Schiffrin (1996). She, in fact, introduced the notion of discourse markers and defined them as sequentially dependent elements that bracket units of talk and considered them as a set of linguistic expressions that comprised members of such varied word classes as conjunctions (because, and, but, or), interjections (oh), adverbs (now, then), and lexicalized phrases (y'know, I mean). Her main conclusion was that these markers could work at different levels of discourse to connect utterances across different planes (Schiffrin 1996: 312; Schiffrin 2003: 54-75). A decade later Blakemore classified as discourse markers some utterance initial units like so, well, still, after all defining the role these expressions play as marking, signaling or indicating how one unit of discourse is connected to another (Blakemore 2003: 113). Frazer sees discourse markers as serving an integrative function in discourse, contributing to discourse coherence, he defines them as 'discourse glue' and provides their pragmatic classification; his list of discourse markers comprises about 30 lexical items belonging to different classes of words (Frazer 1993: 1-16). Viewed traditionally, discourse markers are considered to be of indeterminable word class and uncertain meaning (Brinton 2003: 141). Vlasyan defines discourse markers as important means of coherence and cohesion, which are necessary for successful communication (2011: 115).

All language analysts mentioned above agree upon the fact that the main function of discourse markers is to provide cohesive ties within discourse fragments. In this article, we will try to show that cohesive function is not the only one, and by far not the most important one that these small language units can perform. To set the units under analysis apart from traditional discourse markers (see above) we define them as pragmatic markers. In addition to cohesive function, pragmatic markers can indicate the relevance of the information provided; besides, they are important means for realizing indirect speech acts and indirect discourse strategies. Below, we provide our definition of pragmatic markers that differs from the definition provided by Frazer, 
who analyzes commentary pragmatic markers and defines them as "linguistically encoded clues, which signal the speaker's potential communicative intentions" (1996: 168). Pragmatic markers are defined by us as non-referential language units that perform not only the role of providing discourse cohesion but also serve as the speaker's means of either introducing some implicit semantic and pragmatic information or indicating the relevance of the information flow and topics shift in interaction. A topic in this case is understood as a coherent aggregate of thoughts introduced by some participant in a conversation, developed either by that participant or another or by several participants jointly, and then either explicitly closed or allowed to peter out (Chafe 2003: 674).

Using componential analysis and the procedure of correlation, we came up with a list of special English pragmatic markers that play a significant role in the communication process and are united by the same invariant implicit semantics of contrast. In addition to performing cohesive functions, they convey implicit information, not only semantic but also pragmatic. Dialogical discourse was chosen as the object of our investigation because it perfectly demonstrates all the interactive characteristics and functional peculiarities of the pragmatic markers under analysis.

\section{Classification of pragmatic markers of English in accordance with their correlative functions}

There is still no acceptable classification of words into parts of speech. The most striking example here is the class of adverbs. Language analyst Palmer (1978: 60), for example, characterizes the class of adverbs in the following way: The adverb in particular is the most peculiar class. It is quite clearly 'a rag bag' or 'dustbin'; the class into which words that do not seem to belong elsewhere are placed.

Let us take, for instance, the words that belong to the class of adverbs: again, already, still, and yet. What part of speech can these words really belong to? We will start with again. Traditionally, it is described as an adverb. So if this is the case, it should possess 
the features of the lexical-grammatical class of adverbs. First of all, adverbs are notional words; it means that they refer to something in the objective reality. However, it is impossible to think of the objective referent of the word again. Notional words perform certain syntactic functions in the sentence. What syntactic function does our unit in question perform in the sentence He took my dictionary again? If it is an adverbial modifier of frequency or time, it would answer the question how often? or when? That, however, is not the case. The same goes for words like already, still, yet, etc. The examples are numerous, and at least one thing is clear enough: those words are anything but adverbs.

McGregor (2014: 83) when dealing with the ways word classes should be classified noted:

But in modern linguistics grammatical behaviour is of primary consideration, although meaning does play a role, and serves as the basis for labelling the classes. The idea is, on the one hand, that not all words show the same grammatical behaviour, and, on the other, there are sufficient commonalities among some groups of words to allow us to make generalizations about them.

Therefore, the grammatical behaviour of a unit is of primary importance for introducing word classes and any investigation of the pragmatic markers would be impossible without an attempt to find a proper place for these units within a parts-ofspeech system.

Traditionally, the following classes of function words are commonly recognized: articles, prepositions, particles, conjunctions, modal words, interjections. While articles, prepositions, and interjections can be easily defined within the system of function words, the situation with particles, conjunctions, and modal words is not so obvious. In order to decide what function words can be defined as particles, conjunctions or modal words, we first need to work out the criteria for such classification. The reason we selected only those three classes of function words for a detailed study is their special place within the system of parts-of-speech. However, in 
speech, they are discourse markers and their most important functions are revealed at the discourse level. It should also be mentioned that a proper use of discourse markers in speech is a serious challenge to those students who study English as a foreign language, and whose native language is either Ukrainian or Russian. Really, how can they use them if they do not know their meaning and their functions in speech? Due to the fact that these "lexical items" are devoid of nominative power, their meaning is by no means referential. The semantic meaning they possess is defective. It is only revealed when discourse fragments are correlated. It is really hard to teach a student how and when he should use these words as they lack referential meaning, and their scope of inherent semantic meanings and pragmatic specifications for usage are difficult to define. The meanings of those units are embedded in their grammatical behavior, in our case - textual functions. Therefore, to come up with a detailed classification, we will have to look for their common textual features and correlative peculiarities. It should be noted in this respect that so far we stick to the term "textual" as any formal classification belongs to the sphere of "language".

As a starting point, let us compare three sentences.

1. It is warm today but it will be cold tomorrow.

2. It is warm today and it will be cold tomorrow.

3. It is warm today even if it is cold tomorrow.

While the sentences contain identical propositions, the use of different connectors but, and, even if - locates them in different situational frames. One event is made foreground (prominent), while the other serves as background. By saying (1), the speaker expects an emotional reaction from the hearer about tomorrow. In the second sentence both events (propositions) are equally highlighted. The third sentence reveals the speaker's intention to make the hearer focus his attention on the first proposition. In other words, the first proposition is made foreground. 
The conclusion is that the use of different connectors allows the speaker to focus the hearer's attention on different aspects of the same proposition. Therefore, the connectors, even the most primitive ones, possess some special 'defective' semantics, even though they are devoid of an ordinary referential power. Their semantics is procedural because it is revealed in the process of correlating propositions. To reveal the meaning of other discourse connectors and to work out their classification, it will be helpful to resort to the identical logical operation of correlating sentences. Let us compare three sentences:

1. After all, Mary is here.

2. On the other hand, Mary is here.

3. Hopefully, Mary is here.

The language units after all, on the other hand, and hopefully are function words. However, within the scope of procedural semantics these items are fundamentally different. In the first sentence the unit after all correlates this sentence with the implicit proposition Mary was not expected to be here. In the second example the unit on the other hand introduces another proposition: something that was "on the one hand" by means of correlation. The second proposition, piece of information, is always presented in the preceding text explicitly. And finally, in the third case hopefully does not possess a correlative function as it refers only to the attached sentence.

Correlation or the absence of correlation is crucial for our investigation as it served the grounds for distinguishing different groups of function words in the English language. All these units perform the function of discourse markers in speech but any classification is a language phenomenon. In accordance with the functions performed at the discourse level, all language units under analysis fall into three groups: (1) Particles, (2) Conjunctions and conjunctive units, (3) Modal words and parenthetic expressions. 
Function words defined by us as particles have the ability to correlate two pieces of information. They bring together two sentences (propositions) within the same text, and what is important, one of those sentences (propositions) is usually implicit, that is, it is not actually present in the text.

Function words defined by us as conjunctions and conjunctive units connect two explicit pieces of information within the same text. They provide logical connection bringing the constituents of the text together, turning it into a single unit and thus making it coherent.

By contrast, language units defined by us as modal words and parenthetic expressions refer only to their respective sentences. They have absolutely no connection with the text as a whole. Their most evident function is to provide the speaker's evaluation of the event described by the sentence.

The Table below presents three classes of function words, pragmatic markers, with a short description of their textual functions. Listed in the third column are examples of language units belonging to the corresponding class.

Table 1. Classification of function words in accordance with their correlative textual functions

\begin{tabular}{|c|c|c|}
\hline $\begin{array}{c}\text { FUNCTION WORD } \\
\text { GROUP }\end{array}$ & TEXTUAL FUNCTION & $\begin{array}{c}\text { EXAMPLES OF } \\
\text { LANGUAGE UNITS }\end{array}$ \\
\hline PARTICLES & $\begin{array}{c}\text { Correlate two propositions }- \\
\text { explicit and implicit }\end{array}$ & $\begin{array}{c}\text { Only, even, at last, } \\
\text { again, after all, still, } \\
\text { so far, anyway }\end{array}$ \\
\hline $\begin{array}{c}\text { CONJUNCTIONS AND } \\
\text { CONJUNCTIVE UNITS }\end{array}$ & $\begin{array}{c}\text { Correlate explicit } \\
\text { propositions }\end{array}$ & $\begin{array}{c}\text { Finally, therefore, besides, } \\
\text { on the other hand }\end{array}$ \\
\hline
\end{tabular}




\begin{tabular}{|c|c|c|}
\hline MODAL WORDS AND & Do not correlate anything. & $\begin{array}{c}\text { Hopefully, possibly, } \\
\text { PARENTHETIC }\end{array}$ \\
EXPRESSIONS & Are attached only to one & foolishly, luckily, evidently \\
proposition & \\
\hline
\end{tabular}

In this article, I am going to focus on the study of pragmatic markers belonging to the particles group, as these units are the bearers of the implicit meaning that is revealed only by means of correlation. At the same time, they are communicatively significant items of speech that call for rigorous linguistic analysis.

\section{General characteristics and classification of particles as pragmatic markers}

The general semantic meaning of pragmatic markers belonging to the group of particles is revealed at the discourse level and is based on their textual function. The main function of the group of particles is to correlate two pieces of information within the same text. The most important thing here is that one piece of information is expressed by the sentence to which it is attached, while the other proposition is expressed implicitly. In order to understand how particles work and provide their classification let us consider the following examples:

1. Only John phoned Mary today.

2. John only phoned Mary today.

3. John phoned only Mary today.

4. John phoned Mary only today.

It seems that the most evident function of only is to introduce the rheme of the utterance. However, if we drop this particle, the sentence structure will remain grammatically correct. At the same time, the rheme can be marked out by intonation or special grammatical devices. To our consideration, identifying the rheme here is definitely not the main function of this particle. What it really does is introducing some implicit information by correlating two propositions. The first proposition is presented explicitly while the second one is implicit. Shifting the position of only leads to a different implicit proposition each time: 
1. Nobody else phoned Mary today.

2. John did nothing else to Mary.

3. John phoned Mary but nobody else.

4. John phoned Mary today but not any other time.

Therefore, it is obvious that the main function of only here is to create some additional, implicit information. In fact, all particles add additional semantics to the text even though it becomes clear only at the level higher than a sentence.

It is important to recognize the unique ability of particles to operate at two language levels. In a sentence, particles are attached to the rhematic words thus marking the new information. At the text level, particles bring together explicit and implicit propositions, which results in additional information. According to Rusko (2011: 199), the semantics of particles is directly related to the phenomenon of implicit meaning.

Replacing one particle with another will result in different implicit information. Let us try using even instead of only: Even John phoned Mary today. The particle adds the following implicit meaning to the utterance: Everybody (and John) phoned Mary today. As we can see, the functions of the particles only and even are completely different. While only restricts the group of those who phoned Mary, even expands it.

It follows that particles are devoid of inherent, self-embedded meaning. What they do have appears when the meanings of two propositions (one explicit and the other implicit) are correlated. Because this phenomenon takes place on the higher, super syntactical level, we opted for the term discourse meaning of particles. The classification of particles we are about to offer is based on their discourse meanings. However, we would like you to look at two more examples first.

1. John is here already.

2. John is here again. 
Both sentences contain some implicit information. However, in the first case the implicit information (John was not here before) is contrasted to the explicit proposition while in the second case the implicit information is added. If we look at the functions of any particle from our list, we will clearly see that it is used either for contrast or addition. Correspondingly, depending on what exactly this particular unit does, all particles fall into contrastive and additive. The subdivision of particles is based on the additional meanings they bring to the text. Contrastive particles fall into temporal, concessive, restrictive-exclusive and restrictive-particularizing. In connection with this it should be noted that the terms "restrictive-exclusive" and "restrictive-particularizing" were taken from "A University English Grammar" by Quirk, Greenbaum, Leech \& Svartvick (1982: 103). However, a correction needs to be made. The authors of the book mentioned above did not study the discourse functions of particles. Instead, they referred them to the group of adverbs functioning as focusing adjuncts. Therefore, the units are the same, even though we added more items with identical textual meanings. A detailed classification of all items defined by me as particles (Volkova 2012: 58) is given below. It should be mentioned in this respect that language units of each category were selected in accordance with the procedure of formal correlation and present a group with a limited number of language units.

Table 2. Classification of particles as pragmatic markers in accordance with their correlative functions in discourse

\begin{tabular}{|c|c|c|}
\hline CATEGORY & $\begin{array}{c}\text { CORRELATIVE } \\
\text { FUNCTION IN } \\
\text { DISCOURSE }\end{array}$ & $\begin{array}{c}\text { LANGUAGE } \\
\text { UNITS }\end{array}$ \\
\hline ADDITIVE PARTICLES & $\begin{array}{c}\text { Introduce implicit information } \\
\text { by means of adding }\end{array}$ & $\begin{array}{c}\text { Again, also, as well, } \\
\text { else, even, too }\end{array}$ \\
\hline CONTRASTIVE & Introduce implicit temporal \\
TEMPORAL PARTICLES & $\begin{array}{c}\text { Already, at last, any } \\
\text { (no) longer, any (no) } \\
\text { chore, so far, still, yet }\end{array}$ \\
\hline
\end{tabular}




\begin{tabular}{|c|c|c|}
\hline $\begin{array}{c}\text { CONTRASTIVE } \\
\text { CONCESSIVE PARTICLES }\end{array}$ & $\begin{array}{c}\text { Introduce implicit concession by } \\
\text { means of contrasting }\end{array}$ & $\begin{array}{c}\text { Actually, after all, } \\
\text { anyhow, anyway, in } \\
\text { fact, really, at any rate, } \\
\text { in any event, in any } \\
\text { case }\end{array}$ \\
\hline $\begin{array}{c}\text { CONTRASTIVE } \\
\text { RESTRICTIVE- } \\
\text { EXCLUSIVE PARTICLES }\end{array}$ & $\begin{array}{l}\text { Introduce implicit contrastive } \\
\text { restriction by means of } \\
\text { excluding }\end{array}$ & $\begin{array}{l}\text { alone, at least, barely, } \\
\text { but, exclusively, just, } \\
\text { only, merely, purely }\end{array}$ \\
\hline $\begin{array}{c}\text { CONTRASTIVE } \\
\text { RESTRICTIVE- } \\
\text { PARTICULARIZING } \\
\text { PARTICLES }\end{array}$ & $\begin{array}{l}\text { Introduce implicit contrastive } \\
\text { restriction by means of } \\
\text { particularizing }\end{array}$ & $\begin{array}{l}\text { Chiefly, especially, in } \\
\text { particular, largely, } \\
\text { mainly, } \\
\text { particularly, primarily, } \\
\text { principally }\end{array}$ \\
\hline
\end{tabular}

In addition to the correlative (discourse) meaning, all particles are bearers of a certain pragmatic meaning. While the semantic meaning is inherent in the semantic structure of the particle and becomes evident by means of correlation, the pragmatic meaning is added to the inherent semantic meaning and appears only in the context. For example, in the utterance Even John phoned Mary today, even could express either negative or positive evaluation of the fact. It can be a reproach or an indirect inducement to phone Mary after all. Due to the fact that pragmatic meanings are individual and context dependent, they cannot be characterized as invariant. The pragmatic potential of particles as pragmatic markers in dialogical discourse will be a special focus in this article.

Additive particles (again, also, as well, else, even, too) do not present any difficulty for our learners of English as they have direct equivalents in the Ukrainian and Russian languages. Accordingly, we will not discuss them in this article. Analogously, two groups - restrictive-exclusive (alone, at least, barely, but, exclusively, just, only, merely, purely) and restrictive-particularizing (chiefly, especially, in particular, largely, mainly, mostly, particularly, primarily, principally) are not considered our 
objective for the same simple reason their scope of use is mostly identical in the English, Ukrainian, and Russian languages.

The central premise of the study of particles as pragmatic markers will become the semantic and pragmatic peculiarities of temporal and concessive particles because these two groups comprise multifunctional units frequently used in natural communication. Moreover, the majority of these mysterious pragmatic markers present a real stumbling block for the English language learners, especially those whose native languages are Ukrainian and Russian.

\section{Temporal particles as pragmatic markers}

Temporal particles include seven units: already, still, yet, so far, at last, any (no) longer, and any (no) more. The basis for treating them together is the fact that all of them possess the invariant semantic meaning of a temporal change. They always imply that the state of things was different before or will be different in the future. This meaning is inherent in their semantic structure and it is invariant for all these units. Individual semantic meanings of temporal particles and the paradigmatic relations between them are shown in the table below. It should be mentioned, however, that it would be wrong to treat them as synonyms only on the basis of their apparently similar semantics. The truth is that all of them possess different additional semantic meanings as well as pragmatic components. The pragmatic components introduce subjective context-dependable information. Correlative implicit semantics of temporal particles is presented in the Table below.

Table 3. Correlative implicit semantics of temporal particles

\begin{tabular}{|c|c|}
\hline TEMPORAL PARTICLE & IMPLICIT MEANING \\
\hline ALREADY & not earlier but NOW \\
\hline AT LAST & not earlier but NOW \\
\hline ANY/NO LONGER & earlier but not NOW \\
\hline
\end{tabular}




\begin{tabular}{|c|c|}
\hline ANY/NO MORE & earlier but not NOW \\
\hline STILL & earlier and NOW but not later \\
\hline YET & not NOW but later \\
\hline SO FAR & NOW but not later \\
\hline
\end{tabular}

As we see from the Table, the main semantic component of temporal particles is correlation of the utterance with a temporal particle with the moment of speaking NOW, which has become a relative starting point. This in its turn correlates the semantic content of a temporal particle with the four key coordinates of the communicative situation - I, YOU, HERE, NOW. Therefore, all temporal pragmatic markers are supposed to play an important role in discourse. On the one hand, they reveal the communicant's intention, and on the other, locate the utterance within a temporal frame.

The invariant semantic meaning of already is "a change with reference to the past". Consider the following fragment: The lobby was empty at such an early hour, and Richard was already at his desk with a tall cup of coffee, The Wall Street Journal, and evidently very little to do (Grisham 2005: 161).

The unit already in the proposition Richard was already at his desk introduces another proposition Richard was not at his desk earlier, which is not expressed formally but is understood by the recipient of the message. Therefore, the sentence under analysis means not only that Richard was at his desk but also that he was not there some time ago. The explicit and implicit pieces of information are anaphorically linked. If we drop already, an important piece of information will disappear.

My teaching experience and a set of tests made me arrive at the conclusion that my students associate already only with the use of the Present Perfect tense. They believe that already is always one of the markers of the Perfect tense, which is not so. Both already and the Perfect form are indicators of some change. Their simultaneous use 
makes the change more evident and adds emotional colouring to the sentence. But even if already is dropped, the semantic meaning of the sentence will remain the same. At the same time, some additional meanings may disappear. Compare, for instance, $\mathrm{He}$ has done his homework and He has done his homework already. The second sentence possesses some pragmatic evaluation of the fact; it expresses the speaker's attitude to his message. Consequently, in speech already can be used with any tense-form wherever appropriate. Therefore, the main function of this unit is to show the speaker's attitude to the change. Consider the following example where the fulfillment of the action described by the sentence in bold print is indicated by the Present Perfect form of the verb. The marker already, however, performs a pragmatic function: it shows the general's instant reaction to the news:

"For fourteen years, I've thought my son dead," the general said, turning to me. "How do you expect me to feel?"

"Glad," I suggested.

"I've already notified the proper authorities," the general said (Conroy 1995: 204).

However, in interrogative utterances the communicative function of already is different: it serves as the illocutionary indicator of an indirect speech act. It can be explained by the fact that, unlike yet, already is devoid of the actual interrogative function. Therefore, whenever already is used in questions, its function is always pragmatic. Let us compare two questions: (1) Are you leaving already? and (2) Are you leaving yet? Only the second utterance is really interrogative; and the answer to the question can be either "yes" or "no". The first utterance is by no means a question: it is a directive. Here the speaker does not expect any answer: his intention is to make the hearer stay.

Quite often in utterances, already serves as the indicator of a pragmatic transposition of a speech act (Pocheptsov 2009: 444-448). Consider the following example: "I wondered if you'd like a set of wheels for your suitcase".

"But I haven't got a suitcase". 
"Why don't I get you a little suitcase with wheels attached. You know, like air hostesses have".

\section{"I've already got a bag".}

"Oh, darling, you can't go around with that tatty green canvas thing. You look like some sort of Marry Poppins person who's fallen on hard times..."

"Mum. It's eight thirty in the morning. It's summer. It's very hot. I don't want any airhostess bag" (Fielding 1996: 8).

In this example, the speaker (Bridget) adds already to her utterance to turn down the present that her mother intends to give to her. Therefore, the utterance turns into an indirect speech act. The further context reveals the fact that Bridget's strategy did not work: Bridget's mother wanted her daughter to accept the present anyway. This leaves Bridget no choice but to express her intention explicitly - I don't want any air-hostess bag.

The invariant meaning of still is "retaining the state of things with a future change". This marker also has a wide range of functions. Let us turn to the following example: "We can't tell Luigi about this," she whispered. "Why not?"

She hesitated, then let it go. "He is paying me two hundred euros a week to tutor you, Marco, and he's complaining about the price. We've argued. He has threatened to find someone else. Frankly, I need the money. I'm getting one or two jobs a week now; it's still the slow season. Things will pick up in a month when the tourists come south, but right now I'm not earning much" (Grisham 2005: 206).

In the utterance It's still the slow season the pragmatic marker under analysis functions as a certain informative operator because it introduces two implicit propositions: a) The season was slow before and b) The season will not be slow later. This additional information is not expressed explicitly but is perfectly understood by the hearer. It 
follows that the utterance It's still the slow season makes the hearer focus not only on the current situation but also on the past and the future. If we delete still from the utterance, this important piece of information will disappear. This temporal marker appears in the utterance only when the speaker does not merely describe the current state of affairs but refers the hearer to a certain moment in the future, when he expects a change to occur. If, for some reason, the expected change does not happen, this marker makes it possible for the speaker to enrich his utterance with an additional negative evaluative component, for example: Roxter has still not replied. This is not like Roxter (Fielding 2014: 25).

Due to its semantics, the marker still has a rich pragmatic potential and often becomes an indirect strategy transposition marker. Consider the following example:

"So, come on, then, Bridget! How's yer love-life!" quipped Geoffrey, giving me one of his special hugs, then going all pink and adjusting his slacks.

"Fine."

"So you still haven't got a chap. Durr! What are we going to do with you!" (Fielding 1996: 300-301).

Here still is a marker of the indirect strategy of negative evaluation: the speaker implies that Bridget did not have a boyfriend in the past and she is not dating anyone now, which is shameful for a girl.

In everyday communicative situations, still acts as an important pragmatic operator that changes the illocutionary force of an utterance. When we say There is still time, the utterance often is an indirect speech act, that of inducement Let us do something now or it will be too late. Similarly, the question Are you still angry with me? is most typically an inducement: Let's make it up. To prove the point, let us look at another example where still is an illocutionary indicator of another indirect speech act, that of a directive:

"Daddy, hi," Casey told him pushing herself up in bed. 
"What are you doing still in bed?" he pivoted around on his heels and stared at Casey with disapproval (Fielding 2010: 310).

The interrogative utterance What are you doing still in bed? changes its illocutionary force and becomes a directive: Get up! and still here adds the additional pragmatic meaning of the desired change to happen.

The invariant semantic meaning of yet can be described as "a future change". In order to analyze the scope of action of this marker let us turn to the following example:

Cindy lowered the phone in her hand and stared at Elvis who was waiting for her at the front door. "No. I haven't been out yet. I was about to take the dog for a walk when you called" (Fielding 2005: 273).

The utterance I haven't been out yet correlates with the implicit proposition that yet brings into the discourse: I'll be out later. The implicit information is further confirmed by the following utterance: I was about to take the dog for a walk when you called. Therefore, yet performs the function of an informative operator as it adds implicit information to the discourse by means of correlation.

It is obvious that the use of yet in interrogative sentences is pretty common in English. Traditionally, questions including yet are described as means of extracting information from the hearer. The expected answer is either "yes" or "no". However, we beg to disagree. A request for information is imbedded in the structure of the sentence per se. The pragmatic marker yet is an indicator of hidden strategies and tactics. Consider the following example:

7.45 p.m. Humph. Was Tom.

"Have you voted yet?"

"Actually, I was on my way," I said.

"Oh yes. To which voting station?"

"The one round the corner." 
Hate it when Tom gets like this. Just because he used to be a member of Red Wedge and go round singing "Sing If You're Glad to be Gay" in a morbid voice, there is no need for him to behave like the Spanish Inquisition (Fielding 1996: 204).

The illocutionary force of the speech act including yet stems from its invariant semantic meaning: "a future change". The utterance is no longer a quesitive (Pocheptsov 2009: 443-444) but an indirect directive: I want you to go to a voting station and vote. The particle becomes an effective tool in realizing the speaker's manipulative strategy. The latter is, however, well hidden. The addresser (Tom) does his best to save face because no one likes being manipulated. Even so, the addressee (Bridget) is well aware of the pressure, which is proved by her comparison of Tom's inducement strategy with the methods of the Spanish Inquisition.

Let us look at another example where yet is also a pragmatic marker of an indirect speech act:

"What about Julia?" Cindy interrupted.

"Julia?" Leigh scoffed. "Julia has yet to honor us with her presence" (Fielding 2005: $33)$.

Here, the grammatical meaning of a future change is combined with the pragmatic meaning of the speaker's confidence that things will indeed become different. This makes the utterance Julia has yet to honor us with her presence not only ironical but also presents an indirect speech act. By simply adding yet, the speaker transposes the utterance into an indirect speech act of negative evaluation: Julia's behaviour is not approved of because she takes the liberty of being late.

The invariant meaning of so far is close to that of yet. These two units are usually considered as semantically identical due to their ability to indicate a temporal change with reference to the future. However, unlike so far, the particle yet has some additional meanings, the ones we discussed in the previous paragraphs. The utterances He is not 
here yet and He is not here so far both introduce the implicit proposition He will (may) be here in the future. The pragmatic peculiarities of yet and so far, however, are different, which explains the fact that they function in different pragmatic contexts. Consider the following example:

Mississippi's reputation as a judicial hellhole, as a dumping ground for thousands of frivolous lawsuits, as a heaven for reckless trial lawyers, had changed almost overnight. Thank you, Ron Fisk. Many firms were beginning to see the first signs of stabilized rates for liability insurance protection. Nothing definite yet, but things looked promising. Thank you, Ron Fisk (Grisham 2005: 433).

In this fragment, the proposition nothing definite yet correlates with the implicit piece of information (proposition) there will be something (definite) in the future. Yet is the marker of this implicit information at the discourse level. In this context, the meaning of a future change expressed by yet is combined with the pragmatic meaning of the speaker's certitude in the fact that something is really going to be different (things looked promising). This pragmatic meaning of the speaker's certitude in the future temporal change will play an important role in establishing the difference between so far and yet.

The functional properties of so far appear quite different. In order to understand how this language unit works, consider the following example:

He walked past four cabins, each with at least three passengers, none of whom looked suspicious. He went to the restroom, locked the door, and waited until the train began to slow. Then it stopped. Zug was a two-minute layover, and the train so far had been ridiculously on time (Grisham 2008: 260).

In this fragment, the proposition expressed by the train so far had been ridiculously on time correlates with the implicit proposition the train may not be on time in the future. It follows that the component "a temporal change in the future" is also present in the semantic structure of so far. However, in this case the speaker is not so certain that the 
temporal change will take place. On the contrary, he hopes that it will never happen and the train will arrive at the place of destination on time. Still he leaves place for some doubt, and he shows it by using the commentary adverb ridiculously. Thus, the semantic meaning of the future change is combined with the pragmatic meaning of the speaker's uncertainty about this change.

As we have seen, though grammatically similar, discourse markers yet and so far have obvious pragmatic distinctions that depend on the speaker's estimation of the future event as either highly possible or problematic. Therefore, these temporal pragmatic markers have different spheres of pragmatic application.

The pragmatic markers any (no) longer and any (no) more are studied together due to their semantic similarities at the discourse level. Both markers have an invariant semantic component "termination of the previous state of events" but their pragmatic peculiarities are obviously different. The choice of these markers depends on the speaker's intention. The use of any (no) more shows that the speaker regards the termination of the previous state as final. On the other hand, any (no) longer suggests that the previous state of events may be resumed in the future. In other words, the difference lies in the pragmatic character of the expected change: the speaker treats it either as final or temporary. Let us consider two examples with no longer and any more. What really matters in both discourse fragments below is the speaker's attitude to the temporal change and, accordingly, it determines the choice of the pragmatic marker:

1. And Jude had heard survey on the radio that by the turn of the millennium a third of all households will be single, therefore proving that at last we are no longer tragic freaks (Fielding 1996: 77).

2. "Anyway, there's no such thing as general knowledge any more," I said indignantly (Fielding 2000: 247). 
The invariant semantic meaning of at last is "a temporal change with reference to the past". On the one hand, at last possesses the same semantic content as the unit already, but on the other, the temporal change revealed by at last is pragmatically different. The presence of at last suggests that the speaker treats the temporal change as something long expected. There seems to be little doubt that at last has a high pragmatic potential. Besides, this particle is informatively charged, which explains the fact that it is often used as an indicator of indirect speech acts and a marker of certain tactics and strategies of communication. Consider the following example:

"Hi, hi," she said, kissing us all, sitting down and gesturing to the waiter for a glass. "How's it going? Bridge, how's it going with Mark? You must be really pleased to get a boyfriend at last".

"At last". Grrr. First jellyfish of the evening (Fielding 2000: 44).

In the given fragment the utterance You must be really pleased to get a boyfriend at last correlates with the implicit proposition You have not had a boyfriend for a long time. The semantic meaning of at last ("a temporal change with reference to the past") is expanded by the additional pragmatic component "a long expected change". The pragmatic marker becomes an important means of rendering pragmatic information as it turns the utterance into an indirect speech act of negative evaluation: the speaker hints that the hearer (Bridget) has not had a boyfriend for a long time because she is not attractive.

In this regard we should mention that the word finally is often mistakenly used as a synonym of at last. However, at the discourse level they reveal different functions - at last correlates explicit and implicit propositions and possesses the semantic meaning of a long expected temporal change while finally correlates explicit propositions and indicates the last event in the succession of other events, though sometimes finally can also bear the pragmatic meaning of an expected change. Anyway, they belong to different categories in our classification and have different application characteristics (Volkova 2011: 19). In fact, these markers are false synonyms (Volkova 2011a: 5-9), 
and adequate translation into Ukrainian or Russian is possible only in case we take into account interactive functions of these units in dialogical discourse (Volkova 2013: 412).

\section{Concessive particles as pragmatic markers}

The group of concessive particles includes nine pragmatic markers - anyway, actually, anyhow, at any rate, in any event, in any case, in fact, after all, really. We excluded from our analysis the concessive markers anyhow, in any event, at any point as they are functional synonyms of anyway yet they are only occasionally used in dialogical discourse. The above mentioned pragmatic markers are united into one functional group because they reveal similar characteristics at the discourse level. Let us consider the following example: Luigi smiled with excitement. With a little luck, his cameras were about to record Marco getting nabbed. Maybe they would kill him right there in the living room, captured on film. Perhaps the plan would work after all (Grisham 2005: 263).

The particle after all introduces the following implicit information: the plan was not expected to work; it was destined to fail, as there were a lot of obstacles. As we see, the implicit information appears as the result of correlating two propositions. The facts implied are opposed to the events that are explicitly stated. The semantic structure of after all includes another semantic component, that of concession: though the plan was destined to fail.

This observation is crucial for our research because it served as the basis for distinguishing other pragmatic markers that possess the same concessive semantics. The analysis of the above-mentioned pragmatic markers proves that their characteristics may be different depending on whether they are viewed as components of a single utterance or parts of higher, discourse-level units. At the utterance level, concessive pragmatic markers are syntactically independent elements attached either to the whole utterance or to one of its components. At the discourse level, however, 
they introduce some additional concessive information by correlating explicit and implicit propositions. The latter function is common for all pragmatic markers of the group.

The semantic content of anyway can be explained in the following way: "a speech event has taken place or will take place despite the circumstances". Thus, when we say Thank you anyway, we want to imply that though we did not get what we wanted, we appreciate somebody's help. The explicit information revealed by this pragmatic marker - expressing your gratitude - is opposed to the desired implicit information: either the help was of no use to you or the person could not help you at all.

The semantic meaning of contrastive concession enriches anyway with numerous context-dependable pragmatic meanings. Consider the following example:

"Do you ever see her?" he asked with a touch of self-pity. "Across a crowded commissary, so to speak. Don't worry, I always give your love." "And does she even remember me?" "Are you kidding? Anyway, take care of yourself. Speak to you next week." It was oddly when he hung up that Sandy realized that his father had not directly answered his question (Segal 1995: 105).

Here anyway is used as a pre-closing device. The use of this pragmatic marker shows the speaker's intention to signal to the hearer that the conversation is over: Sandy's father does not feel like discussing an unpleasant subject about his wife (Sandy's mother), and using anyway allows him to back out of the conversation. The indirect tactic is chosen by the speaker in order to weaken a possible negative perlocutionary effect on the hearer.

The example to follow illustrates the use of anyway as the pragmatic marker of the speaker's intention to show that she thinks the event has taken place despite some objective circumstances: 
I handed her a Silk Cut. "I know exactly what you mean, she said, putting it into her mouth and nodding at me appreciatively. "How come he always comes round to your place anyway? I thought he had some great big mansion in Holland Park" (Fielding 2000: 42).

The utterance that contains anyway correlates with the implicit proposition (though) he is expected to behave differently, because he is a man. The use of this pragmatic marker shows that the speaker performs an indirect speech act of negative evaluation.

The pragmatic markers actually and in fact are described together because of their nearly similar functions in the discourse. Consequently, their semantic meanings are identical. Even so, we choose to use the hedging adjective "nearly" to make it clear that in fact and actually may differ in their pragmatic specifications. Therefore, we cannot define them as absolute synonyms. However, in certain contexts, they become rather close because of the implicit semantics they convey. It can be explained by the fact that both pragmatic markers possess contrastive-concessive semantics, which becomes clear at the discourse level. Both units convey the idea of partial contradiction/correction of the communicant's previous statement. Both actually and in fact are effective tools of introducing that additional information that the speaker considers relevant and necessary.

Our studies have clearly shown that communicants tend to use in fact when they want to correct themselves in order to sound more convincing. When used in this function, in fact becomes an effective pragmatic device for different communicative strategies. Consider the following example: "So what's left?" I ask. "Not much," she says quickly. "In fact, nothing" (Grisham 1996: 61).

In this dialogical fragment the meaning of concession inherent in the semantic structure of in fact can be spelled out in the following way: though I've already answered your question, I'm afraid I wasn't convincing enough. Clearly, in fact is used as a component 403 
of the face-saving strategy. The speaker is well aware of the fact that the Maxim of Quantity (Grice 1985: 222) is flouted, so he uses the pragmatic marker to prove that the given additional information is necessary for him.

The most evident interactive function of actually lies in providing the speaker's disagreement with the hearer's previous statement. In other words, it is aimed at disproving the information provided before. Consider the following example:

The smug witch smiled at Mark and blatantly looked me up and down in a most impolite manner. "Have you come from another party?" she breathed.

"Actually, I'm just on my way to work," I said, at which Mark Darcy half smiled and looked away (Fielding 1996: 170).

The communicative intention of the speaker (Bridget) is to disprove the humiliating and offensive hint concerning her clothes (a bunny girl outfit). For this reason, Bridget's reply sounds ironical. The effect of irony is achieved due to the use of actually.

It follows that actually and in fact are characterized by different interactive functions: actually is mostly used when the speaker disagrees with the hearer and wants to correct the hearer's statement, while the presence of in fact is the speaker's attempt to correct his own speech product.

The semantic meaning of after all, resulting from correlating explicit and implicit propositions at the discourse level, can be disclosed in the following way: "an event happened, will happen or may happen despite objective factors".

It is a well-known fact that sometimes the most important textual information is revealed implicitly. The conventional implicatures (Grice 1985: 226-227) introduced by after all play an important role in discourse interpretation and comprehension as they help the addressee generate inferences. The following example with after all fully demonstrates the conventional implicatures at work: 
"He's willing to go in wherever we want him," Norman said. "And I've spent time with him. He is a Communist, but a realist too. Not at all the raving ideologue."

"It's likely he'd wave Das Kapital in your face?" Edward demanded. Everyone chuckled. "He wants the job, Norman. And from what we can gather, he wants it badly - so he can pass information back to the Russians."

"They are our ally after all," Norman protested, although without much conviction (Isaacs 1988: 253).

The use of after all in this example suggests the presence of the implicit proposition Communists cannot be our ally because of their ideology. This implicit statement discloses important pragmatic information: the real attitude of the Germans towards their temporary ally (the Russians) at the first stage of World War II.

When the pragmatic marker after all is used in the initial position, it fully demonstrates its rich logical and pragmatic potential at bringing various important meanings to the discourse. In addition, after all often acts as a speech manipulating device that signals the speaker's hidden intention to make the hearer change his point of view. Consider the following example:

"I still think I should sing a reprise just before the curtain," she replied. "After all, who are the public flocking to see if not Theodora Hamilton?"

To which Zero Mostel answered, "Zero Mostel" (Segal 1985: 328-329).

The use of after all here reveals the speaker's attempt at reasoning with the hearer, which turns this marker into a component of the manipulative strategy of convincing. Besides, it plays an important role in the pragmatic transposition of a question into a directive. The mere fact that the speaker's (Theodora Hamilton's) attempt failed creates a humoristic effect.

The semantic meaning of really is "contrary to what the hearer thinks". This meaning is not always so evident. Yet, a detailed componential analysis will always reveal the 
presence of the invariant meaning of contrastive concession in the semantic structure of really.

As a pragmatic marker, really is often used in dialogical discourse. In fact, it is often one of the key words used by speakers to convey their communicative intentions. Consider the following example with really as a component of the argumentative strategy:

"Spare me the details," I said. "Just tell me we have an understanding, an arrangement."

"Oh, Lynn. We do. And you'll be glad you took another chance on me, you really will." He smiled through his tears (Heller 2001: 18).

In this dialogical fragment, an unfaithful husband is trying to convince his wife that contrary to her belief, he will never cheat on her again. The use of really strengthens the convincing power of the speaker's words.

The use of really often results in pragmatic transposition of speech acts as this pragmatic marker alone can determine the illocutionary force of the utterance. Consider the following example where both utterances with really are indirect speech acts of negative evaluation. The speaker estimates his own act of buying the sculpture as stupid and not worth the money he paid:

When he walked through the door, he came face-to-face with Imelda, already permanently ensconced in the foyer and looking more abused than the night before. He couldn't help but gawk at the sculpture. Did the pile of brass rods really resemble a young girl? Where was the torso? Where were the limbs? Where was her head? Had he really paid that much money for such an abstract mess? (Grisham 2008: 115).

In the following example really transposes the question into the indirect speech act of inducement:

"I look really old for my age, don't I?" I said miserably. 
"No, you look like a five-year-old in your mother's make-up," he said (Fielding 1996: 148).

Bridget's hidden intention is to induce her friend (Tom) to say that she looks young and attractive. Tom, on the other hand, is well aware of the fact that he is being manipulated and refuses to compliment Bridget. In fact, it is a perfect example of speech manipulation that is studied intensively in modern linguistics (Morozova 2013: 84-91; Radzievskaya 2013: 92-99; Sorokina 2013).

In addition to serving as the key for the correct interpretation of indirect speech acts, really can perform different interactive functions and introduce such communicative strategies as evaluation strategy, correction strategy, argumentative strategy, manipulation strategy, answer-evading strategy, re-continuation strategy, and gapfilling strategy (Volkova 2013a: 35-40). The latter is quite frequent in dialogical discourse. Gap-filling devices help communicants keep conversation going and not to become a "communicative failure" (Korogoda 2013). Communicative gaps appear when, for different reasons, the hearer does not know how to react to the speaker's message. Consider the following example:

"And she's amazingly young-looking - I mean she could pass for twenty-four or twentyfive. You were at school together, weren't you, Bridget? Was she three or four years below you?"

"She's six months older, I said," feeling the first twinges of horror.

"Really?" said Rebecca, then left a long embarrassed pause. "Well, Magda's lucky. She's got really good skin" (Fielding 1996: 147).

Here really is a multifunctional conversational device. Firstly, it is a gap-filler: by using this pragmatic marker Rebecca tries to mask her embarrassment, as she realizes she said a stupid thing and Bridget is hurt. In fact, her speech move is a communicative failure. However, the conversation cannot be finished like that. Therefore, secondly, really is also a component of the re-continuation strategy: it signals that the hearer is still an active 407 
listener and his speech contribution will follow. Consequently, this pragmatic marker is a suitable component in various responsive strategies and tactics (Lukianets 2016).

Sometimes the use of really as a gap-filler helps the speaker gain time in order to react to the message properly as in the example below.

"You sure you don't want me to cancel your clients?" she asked, glancing at the day's appointment book, which was full.

I shook my head. "But I do want you to cancel my trip to the conference next week." "Cancel you trip? Really? You never miss one of those conferences, Dr. Wyman" (Heller 2001: 25).

In this example, the secretary attempts to mask her surprise at hearing unexpected news. Really is used as a gap-filling responsive tactic that helps the secretary think of a proper answer. The echo-question Cancel your trip? is used by the speaker with the same communicative goal.

In dialogical discourse really is often used as a component of the re-continuation strategy. Consider the following example, where really is used to keep the conversation going. It is also a component of the re-opening strategy, which means that it expresses the speaker's reaction to what the previous speaker said and elicits a response:

"My God, Jason," she replied. "don't you realize what the Atlantic Ocean spared you in your childhood? I grew up in the shadow of the Nazis. I saw them take our neighbors away. My family even hid a Jewish girl during the whole war."

\section{"Really?"}

She nodded. "Eva Goudsmit. We grew up like sisters" (Segal 1985: 395).

\section{Pragmatic markers in hedging strategies}

Communicative hedging strategies are closely connected with the theory of politeness (Brown \& Levinson 1987) and the theory of "face" (Goffman 1967). According to Thomas, within politeness theory "face" is best understood as every individual's feeling 
of self-worth or self-image; this image can be damaged, maintained or enhanced through interaction with others (Thomas 1995: 169). We try to stick to observing face norms in order to make our communication felicitous.

According to Yule, whenever you say something that lessens the possible threat to another's face, it can be described as a face-saving act (2010: 135). A face-saving act often results in indirect face-saving strategies. Indirect face-saving strategies, in their turn, make communicants resort to the strategy of hedging. Generally, the notion of "hedging" is very popular in modern linguistics. The Longman Dictionary of Contemporary English defines "hedge" as something that gives protection (1987: 488). As a linguistic notion, it means almost the same: we use hedges when speaking or writing in order to protect ourselves from being too explicit or too exposed. We make our speech vague with the purpose of saving face when it is necessary. In natural communication, hedges become indispensable components of hedging strategies. Pragmatic markers analyzed above can be effectively used for this purpose.

Of all the pragmatic markers characterized by a noticeable hedging potential, the marker anyway stands out as the most informative and multifunctional. It should be mentioned in this respect that a lot depends on the position of this word in the utterance (Volkova 2012: 86). In the utterance-initial position anyway is a marker of the following conversational hedging strategies: the strategy of topic changing, the strategy of closing the topic of conversation, the strategy of implicit evaluation. These strategies are obviously indirect because the meaning of concession inherent in the semantic structure of anyway is implicit. Consider the following example:

"Which countries do you think Germany must be near?" he pressed on.

I thought about it carefully. "France".

"France, I see. So Germany is "near France", is it?"

Something about the way Tom said this made me feel I'd made a cataclysmic gaff. Then it occurred to me that Germany is of course connected to Eastern Germany and therefore it is far more likely to be close to Hungary, Russia or Prague. 
"Prague," I said. At which Tom burst out laughing.

"Anyway, there's no such thing as general knowledge any more," I said indignantly (Fielding 2000: 247).

In the discourse fragment given above anyway is used as a component of the preclosing hedging tactic. Its scope of meaning can be revealed in the following way: though you consider all that funny, I'm not going to develop this embarrassing for me topic. For Bridget, this pre-closing tactic is part of a face-saving strategy. She does not want to look like an ignorant person who does not know the location of Germany.

The following example illustrates the use of anyway as the main component of the strategy of changing the topic of conversation:

"I also know you deserve your nickname of being 'Kissinger's shadow.' Isn't it true that you were as privy as any man alive to every significant decision he ever made?" "That's a slight exaggeration," George replied, trying to affect humility. And then joked, "I mean, he didn't take me into his confidence about marrying Nancy. Anyway, what's the thrust of your book?" (Segal 1985: 502).

The speaker (George) uses anyway in the last utterance of this discourse fragment to introduce the implicit proposition though it might be interesting to you, I don't want to discuss my relations with a well-known politician. The speaker resorts to hedging strategy to weaken a possible negative perlocutionary effect on the hearer. At the same time, George tries to save his face because of a sudden change in the topic of conversation.

Due to the meaning of concessive contrast, anyway can become the most important device for the realization of indirect strategy of evaluation. Let us look at the following discourse fragment: 
Tony hit the roof. "I'll bet that childless old bitch, which put this into your head. I don't want any shrinks butting into our lives," she shouted. "We're perfectly capable of dealing with Heather on our own - I am, anyway" (Segal 1995: 167).

The utterance I am, anyway correlates with the implicit proposition though others may find Heather difficult to deal with. The use of anyway enables the speaker to perform an implicit evaluation and turns the utterance into a component of the indirect hedging strategy.

The discourse fragment to follow is a perfect example of the hedging potential of the temporal pragmatic marker yet:

"Toni," he responded with pleasure. "It's nice to hear from you. What made you call me at this ungodly hour?"

"The whole truth? I've been pining here, hoping you'd make a house call. Since it didn't look like it was going to happen, I phoned your apartment. When I got no answer, I decided to find out whether you were on a heavy date or buried in research. Is there someone in your life yet?" (Segal 1985: 47).

The meaning of "a temporal change in the future" inherent in the semantic structure of yet makes it possible for this pragmatic marker to change the illocutionary force of a speech act. In the present example, yet correlates the utterance Is there someone in your life yet? with the implicit proposition There will be someone in your life sooner or later. This correlation reveals the speaker's well-hidden indirect strategy of inducement because it transforms the interrogative utterance into the indirect speech act of a directive: It's about time for you to find a girlfriend. The speaker resorts to the hedging strategy in order to reduce his responsibility for interfering in somebody's private life, which gives him an opportunity to save face in the process of speech interaction. 
Actually is another pragmatic marker that is often used as a means of actualization of the hedging strategy. Consider the following example:

"Guilty as charged," Warren said. "Who told you that?"

"One of the nurse's aides. Patsy something. Lukas, I think her name is."

"The one with the big - " Tyrone began, then broke off, either because he realized such comments might be considered inappropriate, or because he felt no further words were necessary.

"That's the one," Ricardo said.

"She's pretty hot," Tyrone said.

"If you like that type."

"What's not to like?"

"Actually," Warren broke in. "I've hired Patsy to help take care of my wife" (Fielding 2010: 188).

In the dialogical fragment quoted above actually introduces the following implicit information: though you think I've hired Patsy because of her appearance. The specific procedural concessive semantics of this pragmatic marker makes it a perfect means of fulfilling the face-saving hedging strategy of disproving an offensive hint. In addition, its contrastive-concessive potential helps weaken the negative effect of breaking into the conversation.

The unique ability of pragmatic markers to serve as hedges in speech communication makes them an ideal means of manipulating the listener. Speech manipulation is nearly always performed secretly. The speaker wants to induce the listener to come to certain conclusions, to change his point of view or to perform specific actions. In other words, the speaker acts in his own interests and tries to manipulate the listener. Nobody likes being manipulated, which is why it is not done openly. Speech manipulation strategy is our secret weapon when we want the person we are talking to to act in our interests 
or to provide the information we need. However, if we want to save face, we cannot do it too obviously - the listener should not be aware of it. An effective way to do it is by using small and practically unnoticeable pragmatic markers, especially those possessing implicit meanings.

Manipulation in general and speech manipulation in particular is a complex phenomenon connected with numerous extra-lingual factors. Conversational manipulation, when the speaker tries to manipulate the conversation flow including turn-taking strategies frequently occurs in natural communication. The role of pragmatic markers in interactive manipulation strategies calls for a rigorous analysis.

In any case, such pragmatic markers as anyway, actually, and after all are effective devices suitable for manipulating the hearer. Consider the following example where by using actually the speaker (Bridget), instead of admitting that there is no sugar at home because she is not good at housekeeping, tries to manipulate the hearer in order to change his attitude by providing a contradicting point of view:

He looked at me incredulously, surveying the array of empty wine bottles. "No milk or sugar?"

"The milk's er, just run out and actually I don't know anybody who takes sugar in tea..." (Fielding 2000: 30).

Summing up the results of the research, we represented possible interactive functions of pragmatic markers in English dialogical discourse in Table 4. 
Table 4. Interactive functions of pragmatic markers in dialogical discourse

\begin{tabular}{|c|c|c|}
\hline CATEGORY & PRAGMATIC MARKERS & $\begin{array}{c}\text { CONTEXTUAL INTERACTIVE } \\
\text { FUNCTIONS }\end{array}$ \\
\hline $\begin{array}{c}\text { CONTRASTIVE } \\
\text { TEMPORAL } \\
\text { PRAGMATIC } \\
\text { MARKERS }\end{array}$ & $\begin{array}{c}\text { Already, at last, any (no) } \\
\text { longer, any (no) more, so } \\
\text { far, still, yet }\end{array}$ & $\begin{array}{l}\text { - Illocutionary indicators of a } \\
\text { speech act transposition } \\
\text { - Components in the indirect } \\
\text { strategies and tactics of: } \\
\text { - hedging } \\
\text { - evaluation } \\
\text { - face-saving } \\
\text { - inducement } \\
\text { - manipulation }\end{array}$ \\
\hline $\begin{array}{c}\text { CONTRASTIVE } \\
\text { CONCESSIVE } \\
\text { PRAGMATIC } \\
\text { MARKERS }\end{array}$ & $\begin{array}{c}\text { Actually, after all, anyway, } \\
\text { in fact, really }\end{array}$ & $\begin{array}{l}\text { - Illocutionary indicators of a } \\
\text { speech act transposition } \\
\text { - Components in the indirect } \\
\text { strategies and tactics of: } \\
\text { - hedging } \\
\text { - face-saving } \\
\text { - topic changing } \\
\text { - evaluation } \\
\text { - manipulation } \\
\text { - gap-filling } \\
\text { - topic re-continuation } \\
\text { - } \text { argumentation } \\
\text { - inducement } \\
\text { - reasoning } \\
\text { - disproving }\end{array}$ \\
\hline
\end{tabular}

\section{Discussion and conclusions}

It was the philosopher of language Zeno Vendler (1985: 241-242) who stressed upon the importance of paying attention to the study of small objects. It should be noted that, to our regret, we could not find the original quote in English, so we have to give the Russian variant with our further English interpretation:

Мухи - это менее важный вид живых существ, чем слоны, но тем не менее исследование мух может больше способствовать нашему пониманию природы жизни, чем изучение слонов. 
Flies are less important type of living beings than elephants, but, however, studying the life of flies can contribute more to our understanding the nature of life rather than studying elephants.

Vendler's statement becomes crucial for our research if we compare pragmatic markers with small flies! Indeed, they are small and almost unnoticeable language units but the role they play in speech can hardly be overestimated. In fact, such units are perfect means of introducing important pragmatic information, especially in dialogical discourse, and we tried to prove it in our investigation. Moreover, they bring the utterance into the world of "communicative reality" (Vasko 2013: 32).

Our study of pragmatic markers already, still, yet, so far, at last, any (no) longer, any (no) more, anyway, actually, in fact, after all, really has shown that they have two sets of characteristics: as meaningful units of language in a system and as pragmatic markers in speech. As pragmatic markers, they are important means of rendering implicit pragmatic information necessary for discourse interpretation.

Having used componential analysis we managed to select a group of language units, which possess in their semantic structure the implicit semantic component "contrast". The group includes temporal pragmatic markers already, still, yet, so far, at last, any (no) longer, any (no) more and concessive pragmatic markers anyway, actually, in fact, after all, really. The meaning of contrast becomes evident only if we correlate the utterance that contains a pragmatic marker of the selected group with the implicit proposition this unit introduces. Depending on the nature of contrastive relations, we classified pragmatic markers into temporal and concessive: they introduce either implicit temporal change or implicit concession by means of contrasting the corresponding utterance with the implicit information at the discourse level. Accordingly, all the items under analysis were classified into contrastive-temporal and contrastive-concessive. The unique ability of correlating two pieces of information, two propositions (explicit and implicit) and thus introducing various pragmatic 
meanings to dialogical discourse made it possible for us to define them as pragmatic markers. Pragmatic meanings, however, are not inherent in the semantic structure of the pragmatic markers under analysis. They are peripheral and context-dependable while the semantic meaning is invariant and always remains the same for a definite pragmatic marker.

Discourse analysis combined with speech act analysis helped us reveal pragmatic peculiarities of the pragmatic markers under investigation. It turned out that these items are perfect means of realizing the speaker's communicative intention. Moreover, they serve as indicators of the speech acts pragmatic transposition (introduce indirect speech acts) and effectively participate in introducing indirect communicative strategies and tactics. Our research has shown that pragmatic markers of the selected group can be efficient components in the following communicative strategies and tactics: hedging, face-saving, topic changing, topic re-continuation, evaluation, manipulation, gapfilling, argumentation, inducement, reasoning, and disproving.

Further research on the topic lies in investigating the role of pragmatic markers of the selected group as means of defining discourse personality types in a situational discourse, which is defined by Karasik \& Gillespie (2014: 24) as a kind of activity where we underline not what is said but rather how it is said.

\section{References}

Blakemore, D. (2003). Discourse and relevance theory. In The handbook of discourse analysis. Schiffrin, D., Tannen, D. \& Hamilton, H.E. (eds.). Malden: Blackwell Publishing, p. 100-118.

Brinton, L.J. (2003). Historical discourse analysis. In The handbook of discourse analysis. Schiffrin, D., Tannen, D. \& Hamilton, H.E. (eds.). Malden: Blackwell Publishing, p. 138-160.

Brown, P. \& Levinson, S.C. (1987). Politeness. Some universals in language usage. Cambridge: Cambridge University Press. 
Chafe, W. (2003). The analysis of discourse flow. In The handbook of discourse analysis. Schiffrin, D., Tannen, D. \& Hamilton, H.E. (eds.). Malden: Blackwell Publishing, p. 683-677.

Channell, J. (1994). Vague language. Oxford: Oxford University Press.

Conroy, P. (1995). Beach music. N.Y.: Bantam Books.

Fielding, H. (1996). Bridget Jones's diary. Walden: Picador.

Fielding, H. (2000). Bridget Jones: the edge of reason. London: Picador.

Fielding, H. (2014). Bridget Jones: mad about the boy. N.Y.: Vintage Contemporaries.

Fielding, J. (2005). Lost. N.Y.: Pocket Books.

Fielding, J. (2010). Still life. Doubleday: Seal Books.

Frazer, B. (1993). Discourse markers across language. In Pragmatics and language learning: Monograph series, Vol. 4, p. 1-16.

Frazer, B. (1996). Pragmatic markers. In Pragmatics, 6 (2). Available at:

http://journals.linguisticsociety.org/elanguage/pragmatics/article/download/418/418-

712-1-PB.pdf

Goffman, E. (1967). Interaction ritual: essays on face-to-face behavior. N.Y.: Garden City.

Grice, G.P. (1985). Logic and conversation. In New in foreign linguistics, XVI: Linguistic Pragmatics, Moscow: Progress, p. 217-237. / Grice, G.P. Logika i rechevoye obscheniye. In Novoye $v$ zarubezhnoy lingvistike, XVI: Lingvisticheskaya pragmatika, Moskva: Progress, s. 217-237. / Грайс Г.П. Логика и речевое общение. In Новое в зарубежной лингвистике, XVI: Лингвистическая прагматика, Москва: Прогресс, с. 217-237.

Grisham, J. (1996). The rainmaker. London: Arrow.

Grisham, J. (2005). The broker. N.Y.: Doubleday.

Grisham, J. (2008). The appeal. N.Y.: Bantam Dell.

Heller, J. (2001). Female intelligence. N.Y.: St. Martin's Press.

Isaacs, S. (1988). Shining through. N.Y.: Harper \& Row, Publishers.

Karasik, V.I. \& Gillespie, D. (2014). Discourse personality types. In The XXV annual international academic conference, language and culture, 20-22 October 2014, p. 23-29. Available at: http://www.sciencedirect.com/science/article/pii/S1877042814055566 
Korogoda, T.M. (2013). Strategies and tactics of communicative failure repair in the English conversational discourse. Thesis for the Candidate Degree in Philology, Speciality 10.02.04. - Germanic Languages. Kyiv National Linguistic University, Kyiv. / Korogoda, T.M. Stratehiyi $i$ taktyky podolannya komunikatyvnykh zboyiv $v$ anhlomovnomu dialohichnomu dyskursi. Dysertatsiya na zdobuttia vchenoho stupenia kandydata filolohichnyx nauk. Kyivs'kyi natsional'nyi linhvistychnyi universytet, Kyiv. / Корогода Т.М. Стратегії i тактики подолання комунікативних збоїв в англомовному діалогічному дискурсі. / Дис. ... канд. філол. наук / Київський національний лінгвістичний університет. 10.02.04. - германські мови. Київ.

Longacre, R.E. (1976). Mystery particles and affixes. In Papers from the twelfth regional meeting of the Chicago linguistic society. Salikoko, S.M., Carol, A.V. \& Sanford, B. S. (eds.). Chicago: Chicago Linguistic Society, p. 468-475.

Longman dictionary of contemporary English. New edition (1987). Harlow: Longman Group UK Limited.

Lukianets, M.H. (2016). Responsive strategies and tactics in Modern English dialogical discourse. Thesis for the Candidate Degree in Philology, Speciality 10.02.04. - Germanic Languages. Kyiv National Linguistic University, Kyiv. / Lukianets, M.H. Responsyvni stratehiyi i taktyky v suchasnomu anhlomovnomu dialohichnomu dyskursi. Dysertatsiya na zdobuttia vchenoho stupenia kandydata filolohichnyx nauk. Kyivs'kyi natsional'nyi linhvistychnyi universytet. Kуіv. / Лук'янець М.Г. Респонсивні стратегіï і тактики в сучасному англомовному діалогічному дискурсі. / Дис. ... канд. філол. наук / Київський національний лінгвістичний університет. 10.02.04. - германські мови. Київ.

McGregor, W.B. (2014). Linguistics. An introduction. London: Bloomsbury.

Morozova, E.I. (2013). Speech manipulation in a multi-party interactive field. In Messenger of Kyiv national linguistic university, Philology, 16(2). Kyiv: KNLU Publishing Centre, p. 84-89. / Morozova, E.I. Speech manipulation in a multi-party interactive field. In Visnyk Kyivs'koho natsional'noho linhvistychnoho universytetu, Filolohiya, 16(2). Kyiv: Vydavnychyi Tsentr KNLU, s. 84-89. / Morozova, E.I. Speech manipulation in a multi-party interactive field. In Вісник Київського національного 
лінгвістичного університету, Філологія, 16(2). Київ: Видавничий центр КНЛУ, c. $84-89$.

Palmer, F. (1978). Grammar. N.Y.: Penguin Books.

Pocheptsov, G.G. (2009). Selected works in linguistics. Kharkov: V.N. Karasin Kharkov National University. / Pocheptsov, G.G. Izbrannye trudy po lingvistike. Kharkov: HNU imeni V.N. Karazina / Поцепцов Г.Г. Избранные труды по лингвистике. Харьков: ХНУ имени В.Н. Каразина.

Radzievskaya, T.V. (2013). Toward the problem of manipulative impact: the recipient and his reactions. In Messenger of Kyiv national linguistic university, Philology, 16(2). Kyiv: KNLU Publishing Centre, p. 92-99. / Radzievskaya, T.V. K voprosu o manipulyativnom vozdeistvii: adresat i ego reaktsii. In Visnyk Kyivs'koho natsional'noho linhvistychnoho universytetu, Filolohiya, 16(2). Kyiv: Vydavnychyi Tsentr KNLU, s. 92-99. / Радзиевская Т.В. К вопросу о манипулятивном воздействии: адресат и его реакции. In Вісник Київського національного лінгвістичного університету, Філологія, 16(2). Київ: Видавничий центр КНЛУ, с. 92-99.

Rusko, T. (2011). On semantics and pragmatics of concessive particles in Modern English. In SANTALKA: Philologija, edukologiya, 19(2). Available at: http://www.cpe.vgtu.lt/index.php/cpe/article/viewFile/cpe.2011.20/pdf

Quirk, R., Greenbaum, S., Leech G. et al. (1982). A university grammar of English. Moscow: Vysšaja škola.

Schiffrin, D. (1996). Discourse markers. N.Y.: Cambridge University Press.

Schiffrin, D. (2003). Discourse markers: language, meaning and context. In The handbook of discourse analysis. Schiffrin, D., Tannen, D. \& Hamilton, H.E. (eds.). Malden: Blackwell Publishing, p. 54-75.

Segal, E. (1985). The class. N.Y.: Bantam Books.

Segal, E. (1995). Prizes. N.Y.: Ivy Books.

Sorokina, L.Ye. (2013). Verbal manipulation in Modern English dialogical discourse: communicative, cognitive and gender aspects. Thesis for the Candidate Degree in Philology, Speciality 10.02.04. - Germanic Languages. Kyiv National Linguistic University, Kyiv. / Sorokina, L.Ye. Movlenneva manipulyatsiya $v$ suchasnomu 
anhlomovnomu dialohichnomu dyskursi: komunikatyvno-kohnityvnyi $i$ hendernyi aspekty. Dysertatsiya na zdobuttia vchenoho stupenia kandydata filolohichnyx nauk. Kyivs'kyi natsional'nyi linhvistychnyi universytet. Kyiv. / Сорокіна Л.С. Мовленнєва маніпуляція в сучасному англомовному діалогічному дискурсі: комунікативнокогнітивний $i$ гендерний аспекти / Дис. ... канд. філол. наук / Київський національний лінгвістичний університет. 10.02.04. - германські мови. Київ.

Stubbs, M. (1983). Discourse analysis. The sociolinguistic analysis of natural language. Chicago: The University of Chicago Press.

Thomas, J. (1995). Meaning in interaction: an introduction to pragmatics. London \& New York: Longman.

Vasko, R.V. (2013). Sign system of language \& virtual reality in the projection into sphere of social communication. In Messenger of Kyiv national linguistic university, Philology, 16(2). Kyiv: KNLU Publishing Centre, p. 28-32. / Vas'ko, R.V. Linhvosemiotyka i virtual'na real'nist' u proektsiyi na svit sotsial'noyi komunikatsiyi. In Visnyk Kyivs'koho natsional'noho linhvistychnoho universytetu, Filolohiya, 16 (2). Kyiv: Vydavnychyi Tsentr KNLU, s. 28-32. / Васько Р.В. Лінгвосеміотика і віртуальна реальність у проекції на світ соціальної комунікації. / In Вісник Київського національного лінгвістичного університету, Філологія, 16(2). Київ: Видавничий центр КНЛУ, с. 28-32.

Vendler, Z. (1985). Illocutionary suicide. In New in foreign linguistics, XVI: Linguistic Pragmatics, Moscow: Progress, p. 238-250. / In Novoye v zarubezhnoy lingvistike, XVI: Lingvisticheskaya pragmatika, Moskva: Progress, s. 238-250. / Вендлер 3. Иллокутивное самоубийство. In Новое в зарубежной лингвистике, XVI: Лингвистическая прагматика, Москва: Прогресс, с. 238-250.

Vlasyan, G.R. (2011). Functioning of markers of English conversational discourse. In Bulletin of Irkutsk linguistic university, 4(16), p. 115-120. / Vlasyan, G.R. Osobennosti funktsionirovaniya markerov angloyazychnogo konversatsionnogo diskursa. In Vestnik Irkutskogo universiteta, vypusk 4(16), s. 115-120 / Власян Г.Р. Особенности функционирования маркеров англоязычного конверсационного дискурса. In Вестник Иркутского лингвистического университета, выпуск 4(16), с. 115-120. 
Available at: http://cyberleninka.ru/article/n/osobennosti-funktsionirovaniya-markerovangloyazychnogo-konversatsionnogo-diskursa

Volkova, L. (2011a). Function words in interaction: false synonyms. In Scientific bulletin of UNESCO department of Kyiv national linguistic university, 22, p. 5-9. I Volkova, L. Function words in interaction: false synonyms. In Naukovyi visnyk kafedry UNESCO Kyivs'koho natsional'noho linhvistychnoho universytetu, 22, Kyiv: Vydavnychyi tsentr KNLU, s. 5-9. / Volkova, L. Function words in interaction: false synonyms. In Науковий вісник кафедри ЮНЕСКО Київського наџіонального лінгвістичного університету, 22, Київ: Видавничий центр КНЛУ, с. 5-9.

Volkova, L.M. (2013). Concessive discourse markers: contrastive aspect. In Problems of contrastive semantics. Korolyova, A.V. (ed.), 11. Kyiv: KNLU Publishing Centre, p. 407-413. / Volkova, L.M. Dopustovi dyskursyvni markery: zistavnyi aspekt. In Problemy zistavnoyi semantyky. Korolyova, A.V. (red.), 11. Kyiv: Vidavnychyi tsentr KNLU, s. 407-413. / Волкова Л.М. Допустові дискурсивні маркери: зіставний аспект. In Проблеми зіставної семантики. Корольова А.В. (ред.), 11. Київ: Видавничий центр КНЛУ, с. 407-413.

Volkova, L.M. (2011). Contrastive analysis of English and Ukrainian discourse markers. In Proceedings of Taurida national V.I. Vernadsky university, 24(63), № 2, part 3, Simferopol, p. 15-20. / Volkova, L.M. Zistavnyi analiz dyskursyvnykh markeriv anhliys'koyi ta ukrayins'koyi mov. In Uchenyye zapiski Tavricheskogo natsional'nogo universiteta im. V.I. Vernadskogo, 24(63), № 2, chast' 3, Simferopol, s. 15-20. I Волкова Л.М. Зіставний аналіз дискурсивних маркерів англійської та української мов. In Ученые записки Таврического начионального университета им. В.И. Вернадского, 24(63), № 2, часть 3, Симферополь, с. 15-20.

Volkova, L.M. (2012). Function words in language and speech: secrets of felicitous communication. Kyiv: Kafedra.

Volkova, L.M. (2013a). Illocutionary potential of the discourse marker "really". In Messenger of Kyiv national linguistic university, Philology, 16(2). Kyiv: KNLU Publishing Centre, p. 35-40. / Volkova, L.M. Illocutionary potential of the discourse marker "really". In Visnyk Kyivs'koho natsional'noho linhvistychnoho universytetu, 
Filolohiya, 16(2). Kyiv: Vydavnychyi Tsentr KNLU, s. 35-40. / Volkova, L.M. Illocutionary potential of the discourse marker "really". In Вісник Київського національного лінгвістичного університету, серія Філологія, 16(2). Київ: Видавничий центр КНЛУ, с. 35-40.

Yule, G. (2010). The study of language. N.Y.: Cambridge University Press.

\begin{tabular}{|c|c|}
\hline \begin{tabular}{|l}
\multicolumn{1}{c|}{ Contact data } \\
\multicolumn{1}{c}{ Lidiya Volkova, } \\
CSc., (Philology), \\
\multicolumn{1}{c}{ Professor, } \\
Department of German and \\
Finno-Ugrian Philology, Kyiv \\
National Linguistic University, \\
Velyka Vasylkivska Street, 73, \\
Kyiv, Ukraine. e-mail: \\
troyavol11@gmail.com
\end{tabular} & $\begin{array}{l}\text { Fields of interest } \\
\text { Discourse analysis, } \\
\text { linguistic pragmatics, } \\
\text { sociolinguistics, } \\
\text { psycholinguistics. }\end{array}$ \\
\hline
\end{tabular}

\section{Résumé in English}

The article focuses on the study of pragmatic markers in English dialogical discourse. The author's aim was to reveal specific conditions of functioning of those language units that are devoid of referential and nominative power but perform a significant role in the process of verbal interaction. The author defines pragmatic markers as nonreferential language units that serve as the speaker's means of introducing some implicit semantic and pragmatic information or indicating the relevance of the information provided. Using componential analysis, I came up with a list of special English pragmatic markers that play a significant role in communication process and are united by the same implicit semantics of contrast. Their implicit semantics is revealed by the operation of correlating the utterance with the pragmatic marker to the implicit proposition it introduces in discourse. The following non-nominative language units turned out to reveal similar implicit contrastive semantics: temporal markers already, still, yet, so far, at last, any (no) longer, any (no) more and concessive markers anyway, actually, in fact, after all, really. The next step was to investigate pragmatic 
peculiarities of the selected units. All of them turned out to be bearers of a certain pragmatic meaning. While the semantic meaning is inherent in the semantic structure of the marker, the pragmatic meaning appears in the context or communicative situation. Pragmatic markers of the selected group are used in discourse as means of realization of the speaker's communicative intention and serve as illocutionary indicators of indirect speech acts and accordingly, they are engaged in a speech act pragmatic transposition. Besides, they are important components of indirect communicative strategies and tactics of face-saving, topic changing, topic recontinuation, evaluation, hedging, manipulation, gap-filling, argumentation, inducement, reasoning, and disproving.

Keywords: pragmatic marker, dialogical discourse, function words, correlation, implicit meaning, communicative intention, illocutionary indicator, pragmatic transposition, speech act, communicative strategy.

\section{Résumé in German}

Der Artikel befasst sich mit dem Studium der pragmatischen Marker in dem englischen dialogischen Diskurs. Das Hauptziel des Artikels war es, die spezifischen Bedingungen für das Funktionieren von den Spracheinheiten zu identifizieren, die keine Referenzund Nominativbedeutungen haben, sondern eine wesentliche Rolle im Prozess der verbalen Interaktion spielen. Wir definieren pragmatische Marker als nichtreferentielle Spracheinheiten, die dem Sprecher ermöglichen, im Diskurs implizite semantische und pragmatische Informationen einzuführen und auch die Relevanz der bereitgestellten Informationen anzugeben. Mit Hilfe der Komponentenanalyse haben wir eine Liste von den speziellen englischen pragmatischen Markern erstellt, die eine wichtige Rolle im Kommunikationsprozess spielen und durch die gleiche implizite Semantik des Kontrasts vereint sind. Ihre implizite Semantik zeigt sich durch die Korrelation der Äußerung, die den pragmatischen Marker enthält, zu der impliziten Proposition, die dieser Marker in den Diskurs einführt. Die folgenden nichtnominativen Spracheinheiten stellten sich heraus, ähnliche implizite kontrastive 
Semantik aufzudecken: temporale Marker already, still, yet, so far, at last, any (no) longer, any (no) more und Konzessive Marker anyway, actually, in fact, after all, really. Unser nächster Schritt war es, die pragmatischen Besonderheiten der ausgewählten Einheiten zu untersuchen. Die Studie zeigte, dass all diese Wörter besondere pragmatische Bedeutungen haben. Während die semantische Bedeutung der semantischen Struktur des Markers innewohnt, erscheint die pragmatische Bedeutung im Kontext oder in der kommunikativen Situation. Die pragmatischen Marker dieser Gruppe werden im Diskurs als Mittel zur Verwirklichung der kommunikativen Intention des Sprechers verwendet und dienen als illokutionäre Indikatoren der indirekten Sprechakte, und entsprechend engagieren sie sich in einer pragmatischen Transposition der Sprechakte. Außerdem sind sie die wichtigen Bestandteile der indirekten kommunikativen Strategien und Taktiken von Gesichtswahrung, Themenwechsel, Fortsetzung des vorigen Themas, Bewertung, Verwendung von Heckenausdrücken, Manipulation, Füllung der Lakunen, Argumentation, Anreiz, Begründung und Widerlegung.

Stichwörter: pragmatischer Marker, dialogischer Diskurs, Funktionswörter, Korrelation, implizite Bedeutung, kommunikative Intention, illokutionärer Indikator, Sprechakt, kommunikative Strategie.

\section{Résumé in French}

L'article se concentre sur l'étude des marqueurs pragmatiques dans le discours dialogique anglais. Notre objectif principal était de révéler les conditions spécifiques de fonctionnement des unités linguistiques qui sont dépourvues de valeurs référentielle et nominative, mais qui jouent un rôle important dans le processus d'interaction verbale. Nous définissons les marqueurs pragmatiques comme des unités linguistiques nonréférentielles qui permettent au locuteur d'introduire l'information sémantique et pragmatique implicite dans le discours ou bien d'indiquer la pertinence de l'information fournie. À l'aide de l'analyse composante, nous avons proposé une liste particulière de marqueurs pragmatiques anglais qui jouent un rôle essentiel dans le processus de 
communication et qui sont unis par la même sémantique implicite de contraste. Leur sémantique implicite est révélée par l'opération de corrélation entre l'énoncé avec le marqueur pragmatique et la proposition implicite qui est introduite dans le discours par ce marqueur. Les unités linguistiques non-nominatives suivantes ont révélé la même sémantique implicite contrastive: les marqueurs temporels already, still, yet, so far, at last, any (no) longer, any (no) more et les marqueurs concessifs anyway, actually, in fact, after all, really. Ensuite, nous avons examiné les particularités pragmatiques des unités sélectionnées. Il s'est trouvé que tous ces mots possèdent des certains sens pragmatiques. Tandis que le sens sémantique est inhérent à la structure sémantique du marqueur, le sens pragmatique apparaît dans le contexte ou dans la situation communicative. Les marqueurs pragmatiques du groupe sélectionné sont utilisés dans le discours comme le moyen de réalisation de l'intention communicative du locuteur et servent d'indicateurs illocutoires des actes de langage indirects et, en conséquence, ils sont engagés dans une transposition pragmatique d'un acte de langage. En outre, ces marqueurs pragmatiques sont des composants importants des stratégies et des tactiques communicatives indirectes de sauver la face, changer le sujet, revenir au sujet précédent, évaluer quelque chose, éviter de répondre ou répondre à côté, manipuler, combler les lacunes de la communication, argumenter, motiver, justifier et réfuter.

Mots-clés: marqueur pragmatique, discours dialogique, mots fonctionnels, corrélation, sens implicite, intention communicative, indicateur illocutoire, transposition pragmatique, acte de langage, stratégie communicative.

\section{Résumé in Russian}

Статья посвящена исследованию прагматических маркеров в англоязычном диалогическом дискурсе. Основная цель статьи - выявить особые условия функционирования языковых единиц, которые лишены референциального и номинативного значений, однако играют важную роль в процессе вербальной интеракции. Автор определяет прагматические маркеры как неноминативные языковые единицы, которые позволяют говорящему вводить в дискурс 
имплицитную семантическую и прагматическую информацию, а также указывать на релевантность представленной информации. Компонентный анализ позволил выделить отдельную группу англоязычных прагматических маркеров, которые играют важную роль в процессе коммуникации и объединены общим имплицитным семантическим значением противопоставления. Имплицитная семантика прагматических маркеров обнаруживается путём операции соотнесения высказывания, в котором содержится прагматический маркер, с имплицитной пропозицией, которую данный маркер вводит в дискурс. Идентичную имплицитную семантику противопоставления обнаружили следующие языковые единицы: темпоральные маркеры already, still, yet, so far, at last, any (no) longer, any (no) more и уступительные маркеры anyway, actually, in fact, after all, really. Автор также проанализировал прагматические значения выделенных единиц. Исследование показало, что все эти слова обладают особыми прагматическими значениями. В то время как семантическое значение заложено в семантической структуре маркера, прагматическое значение зависит от контекста или ситуации общения. Прагматические маркеры данной группы являются в дискурсе средствами реализации коммуникативной интенции говорящего и служат иллокутивными индикаторами косвенных речевых актов. Соответственно, они играют важную роль в прагматическом транспонировании высказываний. Прагматические маркеры данной группы также могут являться компонентами стратегий и тактик сохранения лица, смены темы диалога, возвращения к предыдущей теме диалога, оценки, манипуляции, заполнения коммуникативных лакун, аргументации, побуждения, обоснования и опровержения.

Ключевые слова: прагматический маркер, диалогический дискурс, служебные слова, корреляция, имплицитное значение, коммуникативная интенция, иллокутивный индикатор, речевой акт, коммуникативная стратегия. 
Article was received by the editorial board 1. 03.17;

Reviewed 30.03.17. and 13.04.17.

Similarity Index 8\%. 